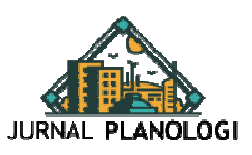

\title{
TIPOLOGI PERMUKIMAN KAWASAN PESISIR KECAMATAN SEMARANG UTARA
}

\author{
Rachmad Winarko Suhar Putra ${ }^{1}$, \\ Bitta Pigawati $^{2}$ \\ Departemen Perencanaan Wilayah dan Kota, Universitas Diponegoro ${ }^{1,2}$ \\ Penulis Korespondensi e-mail: bitta.pigawati@pwk.undip.ac.id ${ }^{2}$
}

\begin{abstract}
The study area of North Semarang District is the coastal area of Semarang City. The area functions as a high density residential and industrial area. Based on the 2014 Mayor's Decree, North Semarang District is the district with the largest number of slum settlements. The research objective was to study the typology of coastal settlements in North Semarang District. The typology of residential areas is determined based on the condition of the slum level, the quality of the settlement environment and the socio-economic characteristics of the population. Using quantitative descriptive methods and spatial analysis, using remote sensing images as the main data source. The results showed that in the Kelurahan Bandarharjo and Tanjungmas there were slum settlements with heavy slum levels and poor environmental quality. Determining coastal typology is one of the important things to do in order to find out the potential and problems in a residential area. The results of the research can be used as a consideration in implementing a residential environmental improvement program. There are 10 types of settlements with different characteristics in the Study Area.
\end{abstract}

Keywords: Tipology of Settelements, Slum Settlements, Quality of Settlement

\begin{abstract}
ABSTRAK
Wilayah studi Kecamatan Semarang Utara merupakan kawasan Pesisir Kota Semarang. Fungsi kawasan sebagai perumahan dengan kepadatan tinggi dan kawasan industri. Berdasarkan SK Walikota tahun 2014, Kecamatan Semarang Utara merupakan Kecamatan dengan jumlah permukiman kumuh terbanyak. Tujuan penelitian untuk mengkaji tipologi permukiman kawasan pesisir Kecamatan Semarang Utara. Tipologi kawasan permukiman ditentukan berdasarkan kondisi tingkat kekumuhan, kualitas lingkungan permukiman serta karakteristik sosial ekonomi penduduk. Menggunakan metode deskriptif kuantitatif dan analisis spasial, dengan memanfaatkan citra penginderaan jauh sebagai sumber data utama. Hasil penelitian menunjukkan bahwa di Kelurahan Bandarharjo dan Tanjungmas terdapat permukiman kumuh dengan tingkat kekumuhan berat dan kualitas lingkungan buruk. Penentuan tipologi pesisir merupakan salah satu hal yang penting untuk dilakukan guna mengetahui potensi dan permasalahan pada suatu kawasan permukiman. Hasil penelitian dapat dipergunakan sebagai pertimbangan dalam menerapkan program perbaikan lingkungan permukiman. Terdapat 10 tipe permukiman dengan karakteristik yang bebeda di Wilayah Studi.
\end{abstract}

Kata kunci: Tipologi Permukiman, Permukiman Kumuh, Kualitas Permukiman 
Jurnal Planologi Vol. 18 No. 1, April 2021

Available: http://jurnal.unissula.ac.id/index.php/psa

\section{PENDAHULUAN}

Kota memiliki populasi yang besar, dan cenderung meningkat pesat dari waktu ke waktu (Brueckner \& Helsley, 2011; Jat, Choudhary, \& Saxena, 2017). Salah satu kawasan Kota Semarang yang merupakan pusat dari konsentrasi permukiman yang berkembang adalah Kecamatan Semarang Utara. Kecamatan Semarang Utara merupakan salah satu kecamatan yang berlokasi di pesisir Kota Semarang, berbatasan langsung dengan Laut Jawa. Kecamatan Semarang Utara termasuk Bagian Wilayah Kota (BWK) III (Pemerintah Kota Semarang, 2011). Fungsi BWK III selain ditetapkan sebagai kawasan perkantoran, perdagangan/jasa serta transportasi darat dan laut juga ditetapkan sebagai kawasan perumahan dengan kepadatan tinggi yang meliputi perumahan pusat kota serta kawasan industri. Penduduk Kecamatan Semarang Utara yang berlokasi di bagian pinggir Kota Semarang sebagian besar penduduknya bekerja di sector industri (Bitta Pigawati, Yuliastuti, \& Mardiansjah, 2017).

Pertumbuhan penduduk merupakan permasalahan yang terjadi di kawasan pesisir (Jaitman, 2013) Pertambahan luas lahan permukiman dan pemadatan rumah mukim merupakan konsekuensi logis terbentuknya permukiman kumuh (Ramadhan \& Pigawati, 2014). Kondisi Permukiman erat kaitannya dengan kondisi fisik alam, bangunan dan sosial ekonomi masyarakat (Fichter, 1972). Adanya dukungan fasilitas transportasi seperti pelabuhan dan stasiun kereta di Kecamatan Semarang Utara menyebabkan tingginya aktivitas dan meningkatnya permintaan lahan untuk permukiman. Peningkatan hunian di Kecamatan Semarang Utara tidak hanya hunian bangunan permanen, namun juga hunian non permanen. Hal ini berdampak pada munculnya kawasan-kawasan permukiman kumuh. Kawasan pesisir sebagai daerah pengelolaan ekosistem laut dapat berubah fungsinya menjadi kawasan permukiman yang padat penduduk dikarenakan terkonsentrasinya kegiatan di kawasan pesisir (Mintiea \& Pigawati, 2018). Perubahan guna lahan mampu menjadi pemicu awal munculnya gejala disintegrasi sosio-spasial permukiman karena guna lahan merupakan variabel fundamental yang dampak dan perubahannya mampu mempengaruhi kehidupan manusia dan lingkungan secara (Ali, 2012). Perubahan fungsi kawasan pesisir yang tidak didukung dengan sarana dan prasarana lingkungan yang memadai dapat menyebabkan menurunnya kualitas permukiman dan munculnya permukiman kumuh.

Permukiman kumuh adalah permukiman yang tidak layak huni karena ketidakteraturan bangunan, tingkat kepadatan bangunan yang tinggi, dan kualitas bangunan serta sarana dan 
prasarana yang tidak memenuhi syarat (Pemerintah Republik Indonesia, 2011). Berdasarkan SK Walikota tentang Penetapan Lokasi Lingkungan Perumahan dan Permukiman Kumuh Kota Semarang Tahun 2014, Kecamatan Semarang Utara merupakan kecamatan dengan jumlah pemukiman kumuh terbanyak sehingga perlu mendapatkan banyak perhatian dan penanganan. Kondisi umum permukiman kumuh di Kecamatan Semarang Utara menunjukkan kepadatan bangunan yang tinggi dan lingkungan yang kurang baik. Sarana lingkungan permukiman perlu diperhatikan dalam menentukan kualitas permukiman karena fasilitas sangat dibutuhkan untuk memenuhi hunian yang layak. Sarana yang dapat digunakan untuk menilai kualitas lingkungan permukiman antara lain sarana,pendidikan, sarana ibadah, sarana kesehatan, sarana perdagangan dan pelayanan (Pigawati, Yuliastuti, Mardiansjah, \& Suryani, 2019). Kualitas lingkungan permukiman yang baik pada sebuah kawasan, mampu meningkatkan kesejahteraan dan kesenangan bagi masyarakat yang tinggal didalamnya (Emmanuel, 2012). Sebagian besar bangunan di kawasan kumuh Kecamatan Semarang Utara belum bersertifikat serta terdapat bangunan yang berdiri diatas lahan ilegal. Persebaran permukiman kumuh di Kecamatan Semarang Utara cenderung tumbuh mendekati kawasankawasan strategis (Nafsi, Aspin, Santi, \& Belinda, 2019)

Penelitian serupa yang pernah dilakukan Bitta Pigawati dan Wisnu Pradoto yaitu mengkaji alasan mengapa masyarakat tetap betahan tinggal di permukiman kumuh daerah banjir rob. Alasan penduduk untuk tetap bertahan didaerah banjir rob karena tersedia fasilitas yang cukup memadai serta faktor kedekatan dengan tempat kerja. Penduduk tetap bertahan karena kerugian yang ditimbulkan hanya terkait pada aspek social ekonomi tidak menyangkut aspek keamanan. Salah satu permasalahan permukiman dikawasan Pesisir Kota Semarang adalah keberadaan permukiman kumuh. Permukiman kumuh ini terjadi karena faktor kependudukan dan sosial ekonomi serta tingkat pendidikan yang rendah Penduduk di kawasan pesisir kota Semarang mempunyai karakteristik; tingkat pendidikan rendah, sebagian besar mempunyai mata pencaharian sebagai buruh industri dan berada dalam kondisi miskin, sehingga tidak mempunyai pilihan lain selain bertempat tinggal pada kawasan permukiman kumuh (Pigawati \& Pradoto, 2014)

Berdasarkan fenomena permukiman kumuh dan kondisi kualitas lingkungan di kawasan pesisir Kota Semarang, maka penelitian ini bertujuan untuk mengkaji tipologi permukiman kawasan pesisir khususnya di Kecamatan Semarang Utara. Menggunakan metode deskriptif 
kuantitatif dan analisis spasial, dengan memanfaatkan citra penginderaan jauh sebagai sumber data utama. Penginderaan Jauh dan Sistem Informasi Geografis dapat digunakan untuk memetakan dan menganalisis kondisi penutupan lahan. Pengertian Penginderaan Jauh (Weng, 2010): Remote sensing refers to the activities of recording, observing, and perceiving (sensing) objects or events in far-away (remote) places. In remote sensing, the sensors are not in direct contact with the objects or events being observed.

Tipologi merupakan salah satu pendekatan yang digunakan untuk mengambil suatu kebijakan pada kegiatan perencanaan. Kajian Tipologi Kawasan Permukiman di Kecamatan Semarang Utara yang merupakan kawasan pesisir Kota Semarang memerlukan pemahaman tentang penggunaan lahan, perumahan dan permukiman serta permasalahan yang terjadi di kawasan pesisir. Pembentukan tipologi memiliki tujuan untuk mengembangkan pendekatan kebijakan yang spesifik yang sesuai dengan tipe suatu wilayah tertentu (Arta \& Pigawati, 2015). Penentuan tipologi pesisir merupakan salah satu hal yang penting untuk dilakukan guna mengetahui potensi dan permasalahan yang berbeda pada tiap tipe permukiman. Data dan informasi tentang tipologi daat digunakan sebagai dasar dalam perencanaan pengelolaan kawasan pesisir (Marfai, Cahyadi, \& Anggraini, 2013). Hasil penelitian dapat dipakai sebagai pertimbangan dalam menerapkan program perbaikan lingkungan permukiman di yang bersangkutan.

\section{METODOLOGI}

Wilayah studi penelitian ini adalah Kecamatan Semarang Utara termasuk dalam BWK III. Fungsi BWK III selain ditetapkan sebagai kawasan perkantoran, perdagangan/jasa serta transportasi darat dan laut juga ditetapkan sebagai kawasan perumahan dengan kepadatan tinggi yang meliputi perumahan pusat kota serta kawasan industri. Kecamatan Semarang Utara memiliki luas wilayah 1.193,62 ha, terdiri dari 9 kelurahan, yaitu Kelurahan Bululor, Kelurahan Plombokan, Kelurahan Panggung Kidul, Kelurahan Panggung Lor, Kelurahan Kuningan, Kelurahan Purwosari, Kelurahan Dadapsari, Kelurahan Bandarharjo dan Kelurahan Tanjungmas. Secara geografis, Kecamatan Semarang Utara terletak antara $110^{\circ} 16^{\prime} 20^{\prime \prime}$ - $110^{\circ}$ $30^{\prime} 29^{\prime \prime}$ BT dan $06^{\circ} 55^{\prime} 34^{\prime \prime}-07^{\circ} 07^{\prime} 04^{\prime \prime}$ LS. 


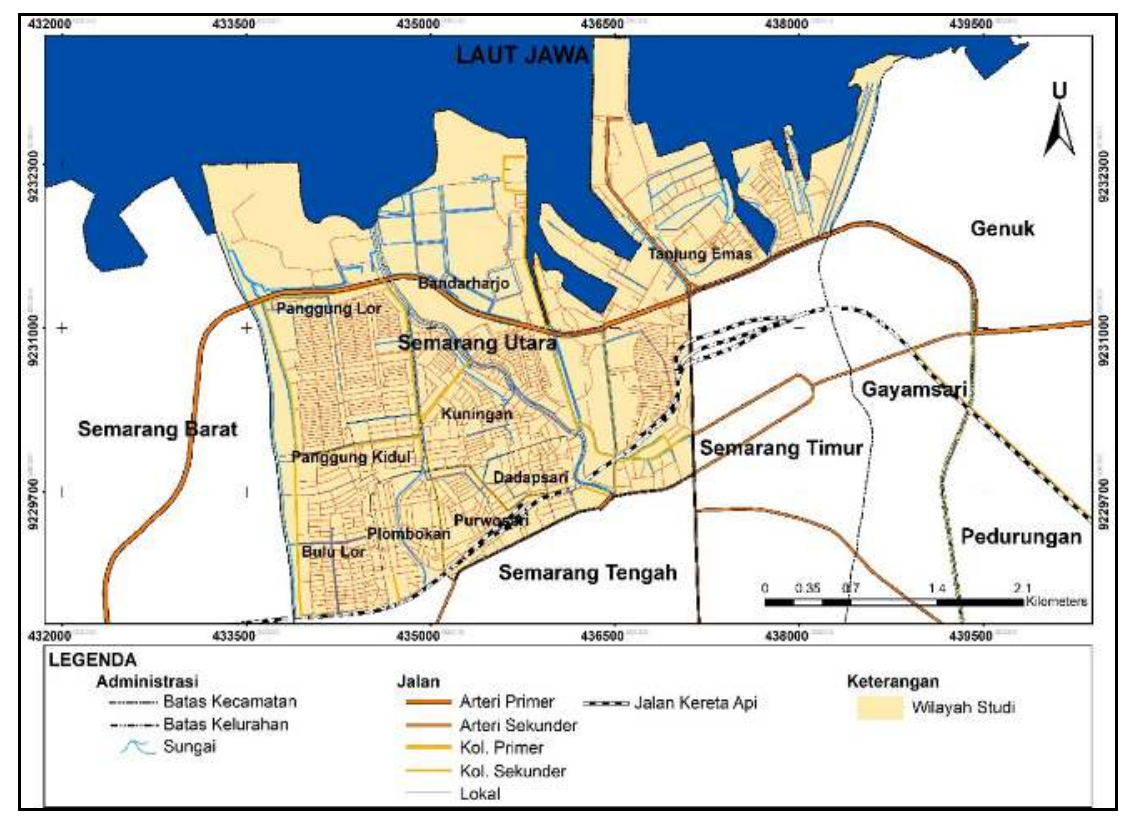

Gambar 1. Peta Wilayah Studi: Kecamatan Semarang Utara

Sumber: Hasil Analisis, 2019

Penelitian ini menggunakan metode deskriptif kuantitatif dan analisis spasial, dengan memanfaatkan citra penginderaan jauh sebagai sumber data utama. Menggunakan teknik analisis overlay, skoring dan pembobotan. Data spasial yang digunakan adalah Citra Quickbird tahun 2017 yang terektifikasi dan Citra Google Earth Pro tahun 2019. Citra Satelit Quickbird memiliki keunggulan mampu menyajikan data dengan resolusi spasial hingga $61-72 \mathrm{~cm}$ (pankromatik) dan 2,44-2,88m (multispektral), sehingga diharapkan mampu memberikan informasi yang akurat dengan tingkat ketelitian yang tinggi (Ratnaningtyas \& Hadi, 2013). Analisis yang dilakukan dalam penelitian ini meliputi beberapa tahap yaitu:

1. Analisis penggunaan lahan dilakukan berdasarkan interpretasi penutup lahan/penggunaan lahan. Menggunakan data citra Quickbird tahun 2017 dan citra Google Earth Pro tahun 2019. Penggunaan lahan dapat diinterpretasi melalui citra penginderaan jauh. Klasifikasi penggunaan lahan berdasarkan penginderaan jauh terbagi menjadi 6, yaitu perkotaan/lahan terbangun, lahan pertanian, lahan perhutanan, perairan, lahan basah dan tanah tandus/gersang (Anderson, 1976). Penggunaan lahan (land use) berdasarkan peraturan perundangan adalah wujud tutupan permukaan bumi baik yang merupakan bentukan alami maupun buatan manusia (Presiden Republik Indonesia, 2004) 
2. Analisis permukiman kumuh bertujuan untuk menganalisis tingkat kekumuhan kawasan permukiman kumuh di Kecamatan Semarang Utara. Permukiman kumuh diidentifikasi berdasarkan SK Walikota tentang Penetapan Lokasi Lingkungan Perumahan dan Permukiman Kumuh Kota Semarang (Walikota Semarang, 2014). Pada analisis kawasan permukiman kumuh, permukiman yang berada di wilayah studi dibedakan menjadi dua kawasan, yaitu; kawasan yang terdapat permukiman kumuh dan kawasan yang tidak terdapat permukiman kumuh. Selanjutnya untuk menentukan tingkat kekumuhan dilakukan analisis menggunakan variabel yang dapat diinterpretasi melalui citra yaitu; kepadatan bangunan, jarak antar bangunan, letak permukiman, fungsi kawasan sekitar dan kondisi jalan lingkungan (Direktorat Pengembangan Pemukiman Direktorat Jenderal Cipta Karya, 2006). Teknik analisis yang digunakan yaitu skoring. Setiap variabel diberikan nilai/skor berdasarkan kriteria yang telah ditentukan. (Tabel 1) menunjukkan variabel, nilai/skor dan kriteria tingkat kekumuhan permukiman kawasan pesisir Kecamatan Semarang Utara.

Table 1. Variabel, Skor dan Kriteria Tingkat Kekumuhan Permukiman

\begin{tabular}{|c|c|c|c|c|}
\hline \multirow{2}{*}{ No } & \multirow{2}{*}{ Variabel } & \multicolumn{3}{|c|}{ Kriteria dan Skor Tingkat Pemukiman Kumuh } \\
\hline & & 20 (Ringan) & 30 (Sedang) & 50 (Berat) \\
\hline 1 & $\begin{array}{l}\text { Kepadatan } \\
\text { Bangunan }\end{array}$ & $\begin{array}{l}\text { luas atap bangunan per } \\
\text { blok permukiman }<65 \%\end{array}$ & $\begin{array}{l}\text { luas atap bangunan per } \\
\text { blok permukiman } 65 \% \text { - } \\
77 \%\end{array}$ & $\begin{array}{l}\text { luas atap bangunan } \\
\text { per blok permukiman } \\
>77 \%\end{array}$ \\
\hline 2 & $\begin{array}{l}\text { Jarak Antar } \\
\text { Bangunan }\end{array}$ & $\begin{array}{l}\text { jarak per bangunan }> \\
3,0 \mathrm{~m}\end{array}$ & $\begin{array}{l}\text { jarak per bangunan } 1,5 \mathrm{~m} \\
-3,0 \mathrm{~m}\end{array}$ & $\begin{array}{l}\text { jarak per bangunan }< \\
1,5 \mathrm{~m}\end{array}$ \\
\hline 3 & $\begin{array}{l}\text { Letak } \\
\text { Permukiman } \\
\text { (kontribusi } \\
\text { terhadap } \\
\text { kekumuhan) }\end{array}$ & $\begin{array}{l}\text { kepentingannya terhadap } \\
\text { wilayah kota kurang } \\
\text { strategis (I) }\end{array}$ & $\begin{array}{l}\text { kepentingannya terhadap } \\
\text { wilayah kota cukup } \\
\text { strategis (II) }\end{array}$ & $\begin{array}{l}\text { kepentingannya } \\
\text { terhadap wilayah kota } \\
\text { sangat strategis (III) }\end{array}$ \\
\hline 4 & $\begin{array}{l}\text { Fungsi Kawasan } \\
\text { Sekitar } \\
\text { (kontribusi } \\
\text { terhadap } \\
\text { kekumuhan) }\end{array}$ & $\begin{array}{l}\text { berada di sekitar } \\
\text { kawasan permukiman } \\
\text { dan lainnya (I) }\end{array}$ & $\begin{array}{l}\text { berada di sekitar } \\
\text { kawasan pusat } \\
\text { pemerintahan dan } \\
\text { perkantoran (II) }\end{array}$ & $\begin{array}{l}\text { berada di sekitar } \\
\text { kawasan pusat } \\
\text { kegiatan bisnis kota } \\
\text { dan perkantoran (III) }\end{array}$ \\
\hline 5 & $\begin{array}{l}\text { Kondisi Jalan } \\
\text { Lingkungan }\end{array}$ & $\begin{array}{l}\text { sudah aspal/paving/cor }> \\
50 \% \text { dengan kondisi } \\
\text { baik }\end{array}$ & $\begin{array}{l}\text { sudah aspal/paving/cor } \\
50 \%-30 \% \text { dengan } \\
\text { kondisi baik }\end{array}$ & $\begin{array}{l}\text { sudah } \\
\text { aspal/paving/cor }< \\
30 \% \text { dengan kondisi } \\
\text { baik }\end{array}$ \\
\hline
\end{tabular}

Sumber: Pedoman Identifikasi Kawasan Permukiman Kumuh Penyangga Kota Metropolitan 2006 dengan modifikasi, 2020 
3. Analisis kualitas lingkungan permukiman, menggunakan variabel; kepadatan bangunan, tata letak bangunan, pohon pelindung, lebar jalan masuk, kondisi jalan masuk dan kelengkapan fasilitas/sarana (B. Pigawati et al., 2019). Setiap variabel diberikan skor dan bobot sesuai besar pengaruh terhadap kualitas lingkungan permukiman. Tabel 2 menunjukkan variabel, bobot, nilai/skor dan kriteria kualitas lingkungan permukiman kawasan pesisir Kecamatan Semarang Utara.

Table 2. Variabel, Bobot, Nilai/Skor dan Kriteria Kualitas Lingkungan Permukiman

\begin{tabular}{|c|c|c|c|c|c|}
\hline \multirow{2}{*}{ No } & \multirow{2}{*}{ Variabel } & \multirow{2}{*}{ Bobot } & \multicolumn{3}{|c|}{ Kriteria dan Skor Kualitas Lingkungan Permukiman } \\
\hline & & & 3 (Baik) & 2 (Sedang) & 1 (Buruk) \\
\hline 1 & Kepadatan & 3 & & & luas atap \\
\hline & Bangunan & & $\begin{array}{l}\text { luas atap bangunan } \\
\text { per blok permukiman } \\
<66 \%\end{array}$ & $\begin{array}{l}\text { luas atap bangunan per } \\
\text { blok permukiman } 65 \% \text { - } \\
78 \%\end{array}$ & $\begin{array}{l}\text { bangunan per } \\
\text { blok } \\
\text { permukiman } \\
>78 \%\end{array}$ \\
\hline 2 & $\begin{array}{l}\text { Tata Letak } \\
\text { Bangunan }\end{array}$ & 3 & $\begin{array}{l}>44 \% \text { ditata secara } \\
\text { teratur per blok }\end{array}$ & $\begin{array}{l}22 \%-44 \% \text { ditata secara } \\
\text { teratur per blok }\end{array}$ & $\begin{array}{l}<22 \% \text { ditata } \\
\text { secara teratur } \\
\text { per blok }\end{array}$ \\
\hline 3 & $\begin{array}{l}\text { Pohon } \\
\text { Pelindung }\end{array}$ & 2 & $>14 \%$ per blok & $7 \%-14 \%$ per blok & $<7 \%$ per blok \\
\hline 4 & $\begin{array}{l}\text { Lebar Jalan } \\
\text { Masuk }\end{array}$ & 2 & $>4 \mathrm{~m}$ per blok & $3 m-4 m$ per blok & $<3$ m per blok \\
\hline 5 & $\begin{array}{l}\text { Kondisi Jalan } \\
\text { Masuk }\end{array}$ & 2 & $\begin{array}{l}>40 \% \text { diperkeras } \\
\text { (paving/semen) }\end{array}$ & $\begin{array}{l}20 \%-40 \% \text { diperkeras } \\
\text { (paving/semen) }\end{array}$ & $\begin{array}{l}<20 \% \\
\text { diperkeras } \\
\text { (paving/seme } \\
\text { n) }\end{array}$ \\
\hline 6 & $\begin{array}{l}\text { Ketersediaan } \\
\text { Fasilitas/Sarana }\end{array}$ & 3 & $\begin{array}{l}\text { tersedia }>11 \text { jenis } \\
\text { per blok }\end{array}$ & $\begin{array}{l}\text { tersedia } 9-11 \text { jenis per } \\
\text { blok }\end{array}$ & $\begin{array}{l}\text { tersedia }<9 \\
\text { jenis per blok }\end{array}$ \\
\hline
\end{tabular}

Sumber: Pigawati et al. 2019 dengan modifikasi, 2020

4. Analisis tipologi permukiman bertujuan untuk menganalisis tipologi permukiman kawasan pesisir kecamatan Semarang Utara berdasarkan ke 3 (tiga) analisis sebelumnya menggunakan teknik overlay serta dilengkapi dengan deskripsi karakteristik sosial ekonominya. Gambar 2 menunjukkan tahapan analisis yang dilakukan dalam penelitian ini. 


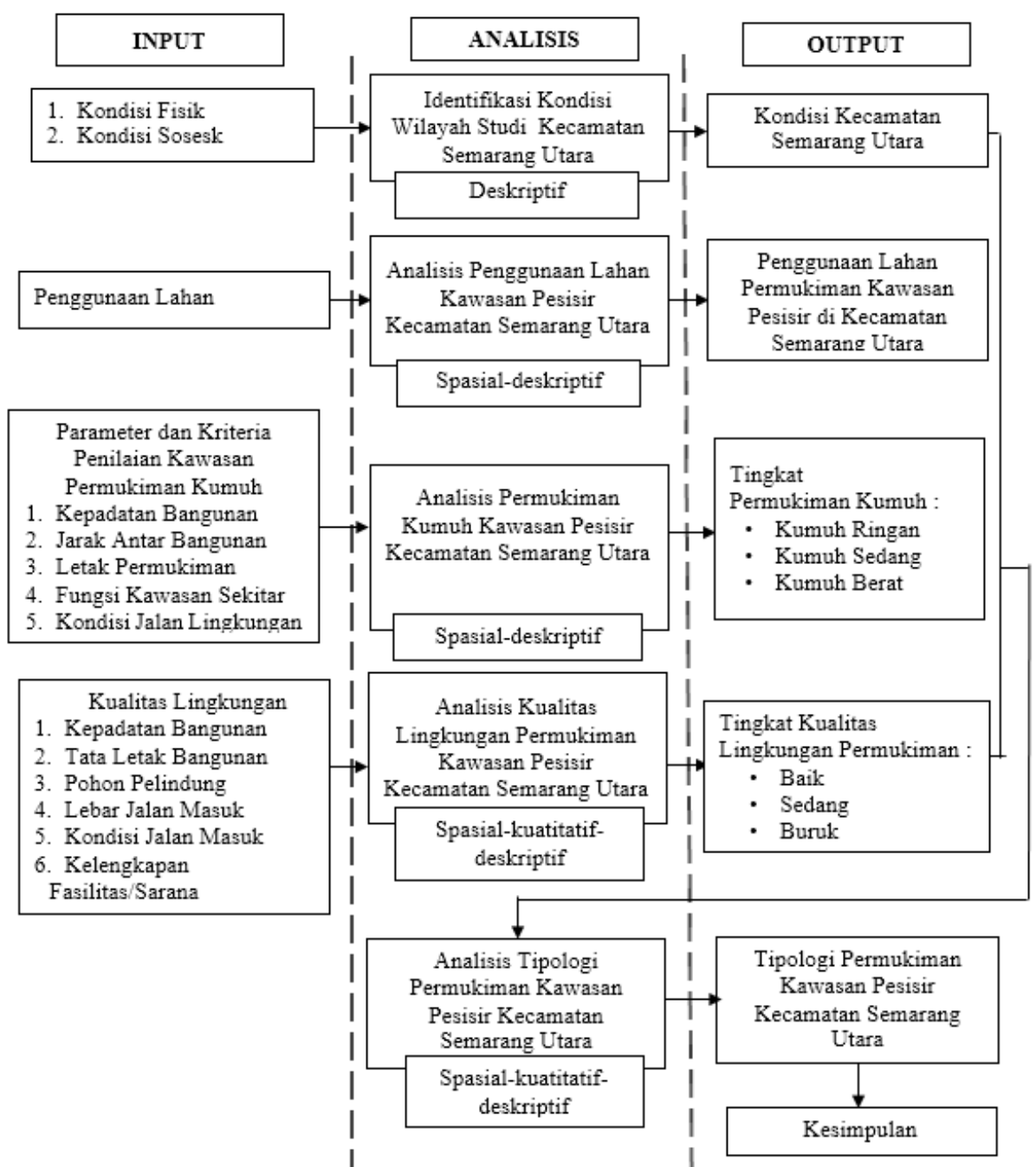

Sumber: Hasil Analisis, 2020

Gambar 2. Diagram Analisis

\section{HASIL DAN PEMBAHASAN}

\subsection{Penggunaan Lahan Permukiman Kawasan Pesisir Kecamatan Semarang Utara}

Penggunaan lahan permukiman di kecamatan Semarang Utara adalah 480,44 (40,25\%). Lahan permukimkan ini sebagian besar tersebar di kelurahan Bulu Lor, kelurahan Kuningan, kelurahan Panggung Lor dengan prosentase sekitar 5\%-8\%. Khusus kelurahan Bandarharjo dan Tanjungmas yang lokasinya berbatasan langsung dengan Laut Jawa penggunaan lahan non permukimannya lebih besar dibanding luas permukiman, karena terdapat penggunaan lahan untuk komplek pelabuhan yang cukup luas, sedangkan penggunaan lahan non permukiman yang cukup luas di kelurahan Panggung Lor disebabkan masih 
terdapatnya lahan kosong dalam komplek pelabuhan. (Gambar 3) menunjukkan persebaran lahan permukiman di Kecamatan Semarang Utara.

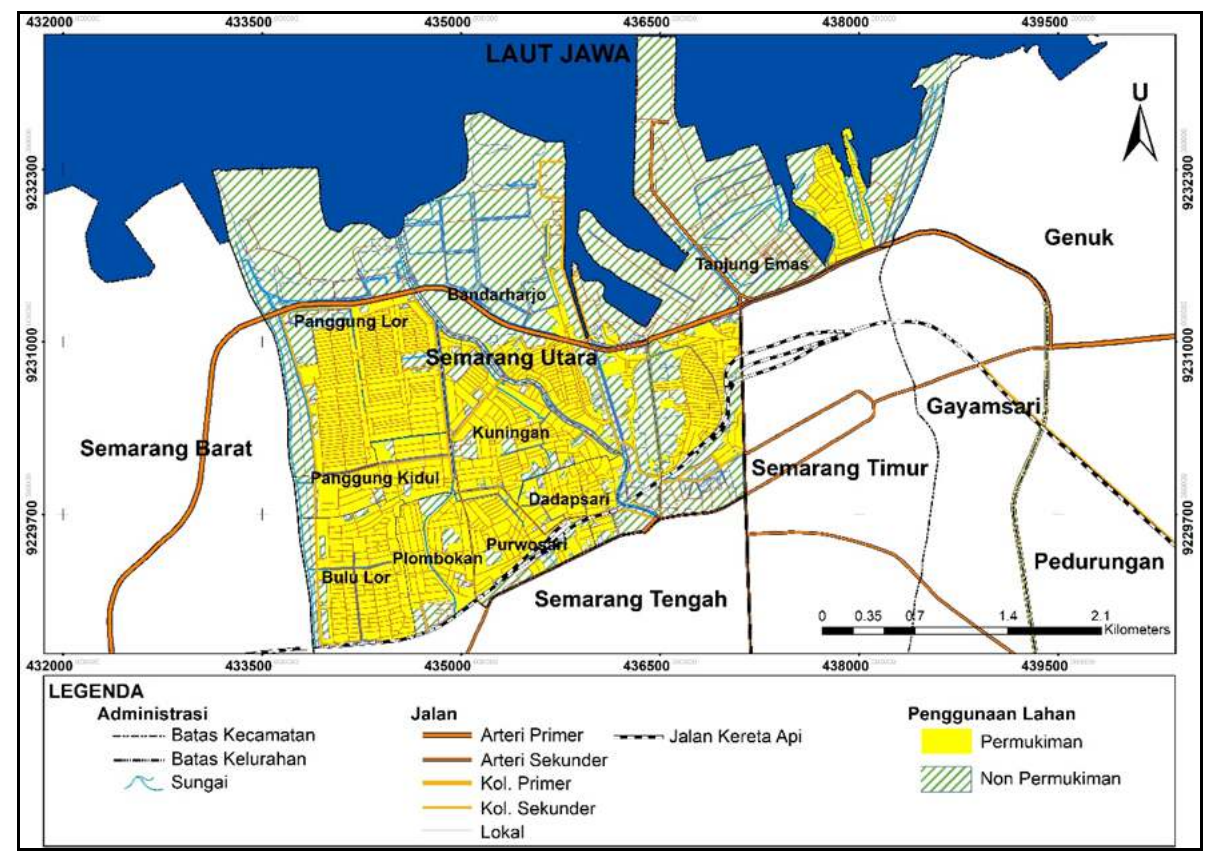

Sumber: Hasil Analisis, 2020

Gambar 3. Penggunaan Lahan Permukiman Kawasan Pesisir Kecamatan Semarang Utara

\subsection{Permukiman Kumuh Kawasan Pesisir Kecamatan Semarang Utara}

Permukiman kumuh di kecamatan Semarang Utara dianalisis berdasarkan 5 variabel (Tabel 3) menunjukkan hasil sebagai berikut:

\section{a) Kepadatan Bangunan}

Kepadatan bangunan tinggi ( $>77 \%)$ sebagian besar terdapat di kelurahan Kuningan $(11,95 \%)$ terdiri dari 2 blok (D1, D5) dan Kelurahan Tanjungmas (28,38\%) terdiri dari 3 blok (I2, I4, I5, I6).

\section{b) Jarak Antar Bangunan}

Jarak antar bangunan blok permukiman kawasan permukiman kumuh pesisir kecamatan Semarang Utara seluruhnya (100\%) masuk kriteria buruk, karena jarak antar blok permukiman di adalah $<1,5 \mathrm{~m}$, kondisi ini terdapat di 27 blok dengan total luas permukiman kumuh 250,51 ha. 
Jurnal Planologi Vol. 18 No. 1, April 2021

\section{c) Letak Permukiman}

Sebagian besar blok permukiman kawasan permukiman kumuh di kecamatan Semarang Utara masuk dalam kriteria I (kepentingannya terhadap wilayah kota kurang strategis), berarti berkontribusi pada tingkat kekumuhan ringan. Letak permukiman I terdapat di 11 blok permukiman yang masuk dalam wilayah kelurahan Bandarharjo, kelurahan Kuningan, kelurahan Panggung Kidul serta kelurahan Tanjungmas dengan persentase 59,97\% dari luas keseluruhan permukiman kumuh di kecamatan Semarang Utara (150,23 ha).

\section{d) Fungsi Kawasan Sekitar}

Hasil analisis kondisi kumuh yang terkait dengan fungsi kawasan sekitar menunjukan sebagian besar blok permukiman kawasan permukiman kumuh di kecamatan Semarang Utara termasuk dalam kriteria I (berada di sekitar kawasan permukiman dan lainnya) terdapat di 11 blok permukiman berada pada wilayah kelurahan Bandarharjo, kelurahan Dadapsari, kelurahan Kuningan serta kelurahan Panggung Kidul dengan persentase 63,61\% dari luas total permukiman kumuh $(159,35 \mathrm{ha})$.

\section{e) Kondisi Jalan Lingkungan}

Sebagian besar jalan lingkungan blok permukiman kawasan permukiman kumuh di kecamatan Semarang Utara menunjukkan kondisi jalan yang baik (aspal/paving/cor $>50 \%$ dengan kondisi baik) terdapat di 21 blok permukiman pada wilayah kelurahan Bandarharjo, kelurahan Dadapsari, kelurahan Kuningan, kelurahan Panggung Kidul serta kelurahan Tanjungmas dengan persentase 98,41\% dari luas total permukiman kumuh (246,52 ha).

Tingkat kekumuhan blok permukiman kawasan permukiman kumuh di Kecamatan Semarang Utara diananlisis berdasarkan 5 variabel (Tabel 3). Kriteria untuk menentukan tingkat kekumuhan dibedakan sebagai berikut:

- $\quad$ Permukiman kumuh ringan (skor 100-150)

- $\quad$ Permukiman kumuh sedang (skor 150-200)

- $\quad$ Permukiman kumuh berat (skor 200-250)

Terdapat 7 blok permukiman dengan tingkat kekumuhan berat di kawasan pesisir kecamatan Semarang Utara yang berlokasi di kelurahan Bandarharjo dan kelurahan Tanjungmas dengan persentase $13,46 \%$ dari luas total permukiman kumuh yang terdapat di kecamatan Semarang Utara (33,72 ha). Tabel 3 menunjukkan tingkat kekumuhan permukiman 
Jurnal Planologi Vol. 18 No. 1, April 2021

kumuh kawasan pesisir kecamatan Semarang Utara sedangkan persebarannya dapat dilihat pada Gambar 4.

Tabel 3. Tingkat Kekumuhan Blok Permukiman Kumuh Kawasan Pesisir Kecamatan Semarang Utara

\begin{tabular}{|c|c|c|c|c|c|c|c|c|c|}
\hline \multirow[b]{2}{*}{$\begin{array}{l}\text { Kelur } \\
\text { ahan }\end{array}$} & \multirow[b]{2}{*}{$\begin{array}{c}\text { Blo } \\
\mathbf{k}\end{array}$} & \multicolumn{5}{|c|}{ Nilai/Skor } & \multirow[b]{2}{*}{$\begin{array}{l}\text { Total } \\
\text { Skor/ } \\
\text { Bobot }\end{array}$} & \multirow[b]{2}{*}{$\begin{array}{c}\text { Tingkat } \\
\text { Permukima } \\
\text { n Kumuh }\end{array}$} & \multirow[b]{2}{*}{$\begin{array}{l}\text { Luas } \\
\text { Blok } \\
\text { (ha) }\end{array}$} \\
\hline & & $\begin{array}{c}\text { Letak } \\
\text { Permuki } \\
\text { man }\end{array}$ & $\begin{array}{c}\text { Kepadata } \\
\mathbf{n} \\
\text { Bangunan }\end{array}$ & $\begin{array}{c}\text { Kondisi } \\
\text { Jalan } \\
\text { Lingkungan }\end{array}$ & $\begin{array}{c}\text { Fungsi } \\
\text { Kawasa } \\
\text { n } \\
\text { Sekitar }\end{array}$ & $\begin{array}{c}\text { Jarak } \\
\text { Antar } \\
\text { Bangu } \\
\text { nan }\end{array}$ & & & \\
\hline \multirow{10}{*}{$\begin{array}{l}\text { Banda } \\
\text { rharjo }\end{array}$} & A1 & 50 & 30 & 20 & 50 & 50 & 200 & Sedang & 4,70 \\
\hline & $\mathrm{A} 2$ & 20 & 30 & 20 & 20 & 50 & 140 & Ringan & 29,66 \\
\hline & A3 & 30 & 20 & 20 & 50 & 50 & 170 & Sedang & 5,46 \\
\hline & A4 & 30 & 50 & 20 & 50 & 50 & 200 & Sedang & 2,32 \\
\hline & A5 & 50 & 50 & 20 & 50 & 50 & 220 & Berat & 0,54 \\
\hline & A6 & 50 & 50 & 50 & 50 & 50 & 250 & Berat & 0,09 \\
\hline & A7 & 50 & 30 & 20 & 50 & 50 & 200 & Sedang & 0,36 \\
\hline & A8 & 50 & 50 & 50 & 50 & 50 & 250 & Berat & 0,16 \\
\hline & A9 & 50 & 30 & 30 & 30 & 50 & 190 & Sedang & 0,24 \\
\hline & A 10 & 50 & 50 & 50 & 50 & 50 & 250 & Berat & 1,11 \\
\hline \multirow{3}{*}{$\begin{array}{c}\text { Dadap } \\
\text { sari }\end{array}$} & $\mathrm{C} 1$ & 50 & 30 & 20 & 30 & 50 & 180 & Sedang & 2,70 \\
\hline & $\mathrm{C} 2$ & 30 & 50 & 20 & 20 & 50 & 170 & Sedang & 15,41 \\
\hline & $\mathrm{C} 3$ & 50 & 30 & 20 & 20 & 50 & 170 & Sedang & 10,40 \\
\hline \multirow{5}{*}{$\begin{array}{c}\text { Kunin } \\
\text { gan }\end{array}$} & D1 & 20 & 50 & 20 & 20 & 50 & 160 & Sedang & 15,98 \\
\hline & D2 & 20 & 20 & 20 & 20 & 50 & 130 & Ringan & 13,76 \\
\hline & D3 & 20 & 30 & 20 & 20 & 50 & 140 & Ringan & 21,85 \\
\hline & D4 & 20 & 30 & 20 & 20 & 50 & 140 & Ringan & 1,96 \\
\hline & D5 & 20 & 50 & 20 & 20 & 50 & 160 & Sedang & 13,96 \\
\hline \multirow{3}{*}{$\begin{array}{l}\text { Pangg } \\
\text { ung } \\
\text { Kidul }\end{array}$} & E1 & 20 & 30 & 20 & 20 & 50 & 140 & Ringan & 8,39 \\
\hline & E2 & 20 & 50 & 20 & 20 & 50 & 160 & Sedang & 3,67 \\
\hline & E3 & 20 & 30 & 20 & 20 & 50 & 140 & Ringan & 24,31 \\
\hline \multirow{6}{*}{$\begin{array}{c}\text { Tanjun } \\
\text { gmas }\end{array}$} & I1 & 50 & 30 & 30 & 50 & 50 & 210 & Berat & 1,54 \\
\hline & $\mathrm{I} 2$ & 50 & 50 & 20 & 50 & 50 & 220 & Berat & 29,42 \\
\hline & I3 & 50 & 20 & 50 & 50 & 50 & 220 & Berat & 0,86 \\
\hline & I4 & 30 & 50 & 20 & 50 & 50 & 200 & Sedang & 26,00 \\
\hline & I5 & 20 & 50 & 20 & 50 & 50 & 190 & Sedang & 11,23 \\
\hline & I6 & 50 & 50 & 20 & 30 & 50 & 200 & Sedang & 4,45 \\
\hline
\end{tabular}

Sumber: Hasil Analisis, 2020 


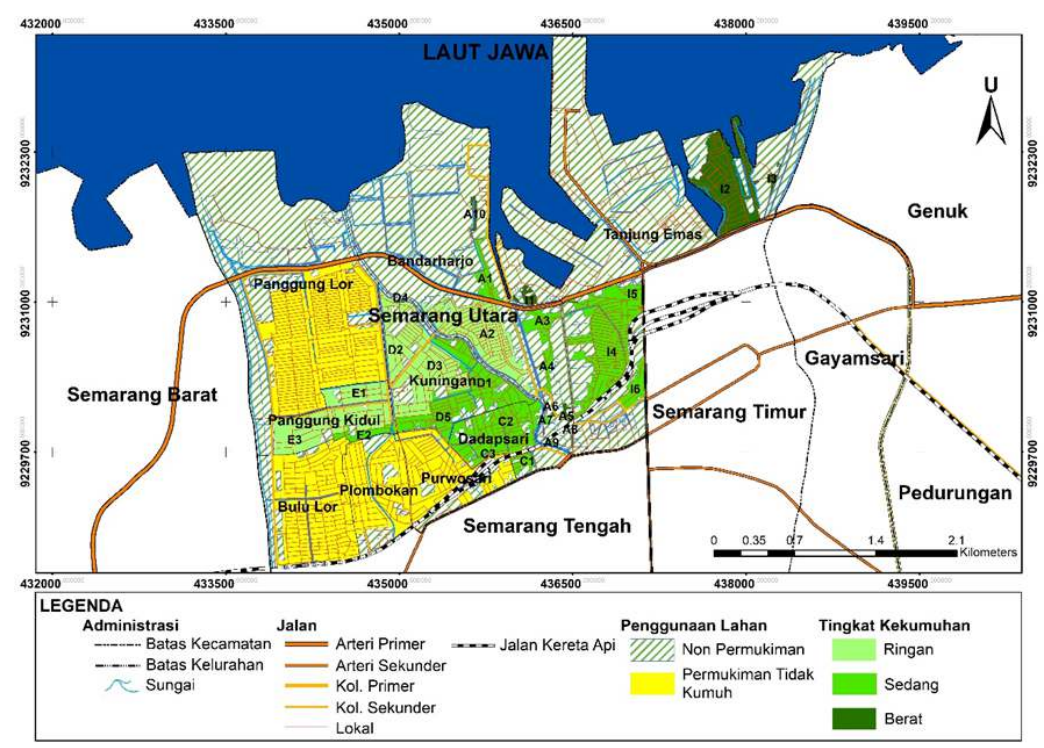

Sumber: Hasil Analisis, 2020

Gambar 4. Tingkat Kekumuhan Permukiman Kawasan Pesisir Kecamatan Semarang Utara

\subsection{Kualitas lingkungan permukiman kawasan pesisir Kecamatan Semarang Utara}

Kualitas lingkungan permukiman kawasan pesisir kecamatan Semarang Utara dianalisis berdasarkan 6 variabel (Tabel 4) yang menunjukkan hasil sebagai berikut:

\section{a) Kepadatan Bangunan}

Kepadatan bangunan sedang (65\% - 78\%) sebagian besar terdapat di kelurahan Bandarharjo (7,28\%) terdiri dari 4 blok (A1, A2, A7, A9), kelurahan Bulu Lor $(7,90 \%)$ terdiri dari 1 blok (B2), kelurahan Plombokan (7,67\%) terdiri dari 2 blok (G1, G2) dan kelurahan Tanjungmas (8,78\%) terdiri dari 3 blok (I1, I2, I5). Kepadatan bangunan tinggi (>78\%) sebagian besar terdapat di kelurahan Panggung Lor (20,36\%) terdiri dari 1 blok (F1).

\section{b) Tata Letak Bangunan}

Tata letak bangunan buruk $(<22 \%$ ditata secara teratur per blok) sebagian besar terdapat di kelurahan Bandarharjo (9,29\%) terdiri dari 10 blok (A1, A2, A3, A4, A5, A6, A7, A8, A9, A10) dan kelurahan Tanjungmas (15,30\%) terdiri dari 6 blok (I1, I2 I3, I4, I5, I6). Tata letak bangunan baik ( $>44 \%$ ditata secara teratur per blok) sebagian besar terdapat di kelurahan Panggung Lor (20,36\%) terdiri dari 1 blok (F1).

\section{c) Pohon Pelindung}

Pohon pelindung sedang ( $7 \%-14 \%$ per blok) sebagian besar terdapat di kelurahan 
Kuningan (14,05\%) terdiri dari 5 blok (D1, D2, D3, D4, D5). Pohon pelindung buruk $(<7 \%$ per blok) sebagian besar terdapat di kelurahan Panggung Lor (20,36\%) terdiri dari 1 blok (F1) dan kelurahan Tanjungmas (14,37\%) terdiri dari 5 blok (I1, I2, I3, I4, I5).

\section{d) Lebar Jalan Masuk}

Sebagian besar jalan masuk blok permukiman kawasan pesisir di Kecamatan Semarang Utara memiliki lebar jalan masuk yang sedang ( $3 \mathrm{~m}-4 \mathrm{~m}$ per blok) terdapat di 19 blok permukiman pada wilayah kelurahan Bandarharjo, Bulu Lor, Dadapsari, Panggung Kidul, Plombokan, Purwosari serta Tanjungmas dengan persentase 49,27\% dari luas total permukiman (236,72 ha). Lebar jalan masuk yang baik ( $>4 \mathrm{~m}$ per blok) sebagian besar terdapat di kelurahan Kuningan (10,32\%) terdiri dari 3 blok (D2, D3, D5) dan kelurahan Panggung Lor $(20,36 \%)$ terdiri dari 1 blok (F1).

\section{e) Kondisi Jalan Masuk}

Sebagian besar jalan masuk blok permukiman kawasan pesisir di Kecamatan Semarang Utara memiliki kondisi jalan masuk yang baik (> 40\% diperkeras paving/semen) terdapat di 32 blok permukiman pada wilayah kelurahan Bandarharjo, Bulu Lor, Dadapsari, Kuningan, Panggung Kidul, Panggung Lor, Plombokan, Purwosari serta Tanjungmas dengan persentase $99,49 \%$ dari luas total permukiman (477,98 ha).

\section{f) Ketersediaan Fasilitas/Sarana}

Sebagian besar ketersediaan fasilitas/sarana blok permukiman kawasan pesisir di Kecamatan Semarang Utara masuk dalam kriteria baik (tersedia $>11$ jenis per blok) terdapat di 7 blok permukiman pada wilayah kelurahan Bandarharjo, Bulu Lor, Kuningan, Panggung Kidul, Panggung Lor, Purwosari serta Tanjungmas dengan persentase $54,32 \%$ dari luas total permukiman (260,97 ha).

Berikut merupakan kriteria untuk menentukan tingkat kualitas permukiman yang dibedakan menjadi:

- Kualitas lingkungan permukiman baik (skor 45-35)

- Kualitas lingkungan permukiman sedang (skor 35-25)

- Kualitas lingkungan permukiman buruk (skor 25-15)

Tabel 4 menunjukkan kualitas lingkungan permukiman kawasan pesisir Kecamatan Semarang Utara. 
Jurnal Planologi Vol. 18 No. 1, April 2021

Tabel 4. Kualitas Lingkungan Blok Permukiman Kawasan Pesisir Kecamatan Semarang Utara

\begin{tabular}{|c|c|c|c|c|c|c|c|c|c|c|c|c|}
\hline \multirow[b]{3}{*}{$\begin{array}{l}\mathbf{N} \\
\mathbf{0}\end{array}$} & \multirow[b]{3}{*}{$\begin{array}{l}\text { Kelur } \\
\text { ahan }\end{array}$} & \multicolumn{9}{|c|}{ Kualitas Lingkungan Permukiman } & \multirow{2}{*}{\multicolumn{2}{|c|}{$\begin{array}{l}\text { Luas Total } \\
\text { Permukiman }\end{array}$}} \\
\hline & & \multicolumn{3}{|c|}{ Baik } & \multicolumn{3}{|c|}{ Sedang } & \multicolumn{3}{|c|}{ Buruk } & & \\
\hline & & Blok & $\begin{array}{r}\text { Luas } \\
\text { (ha) }\end{array}$ & $\%$ & Blok & $\begin{array}{r}\text { Luas } \\
\text { (ha) }\end{array}$ & $\%$ & Blok & $\begin{array}{r}\text { Lu } \\
\text { as } \\
\text { (ha } \\
\text { ) }\end{array}$ & $\%$ & $\begin{array}{r}\text { Luas } \\
\text { (ha) }\end{array}$ & $\%$ \\
\hline 1 & $\begin{array}{l}\text { Bandar } \\
\text { harjo }\end{array}$ & - & 0,00 & 0,00 & A2 A3 A7 & 35,48 & $\begin{array}{r}79,4 \\
9\end{array}$ & $\begin{array}{l}\text { A1 A4 A5 } \\
\text { A6 A8 A9 } \\
\text { A10 }\end{array}$ & $\begin{array}{r}9,1 \\
5\end{array}$ & 20,51 & 44,63 & 9,29 \\
\hline 2 & $\begin{array}{l}\text { Bulu } \\
\text { Lor }\end{array}$ & B2 & 37,95 & $\begin{array}{r}61,1 \\
6\end{array}$ & - & 0,00 & 0,00 & B1 B3 & $\begin{array}{r}24, \\
10\end{array}$ & 38,84 & 62,04 & 12,91 \\
\hline 3 & $\begin{array}{l}\text { Dadap } \\
\text { sari }\end{array}$ & - & 0,00 & 0,00 & $\mathrm{C} 1 \mathrm{C} 2 \mathrm{C} 3$ & 28,51 & $\begin{array}{r}100 \\
00\end{array}$ & - & $\begin{array}{r}0,0 \\
0\end{array}$ & 0,00 & 28,51 & 5,93 \\
\hline 4 & $\begin{array}{l}\text { Kunin } \\
\text { gan }\end{array}$ & D2 D3 & 35,60 & $\begin{array}{r}52,7 \\
5\end{array}$ & D5 & 13,96 & $\begin{array}{r}20,6 \\
8\end{array}$ & D1 D4 & $\begin{array}{r}17 \\
94\end{array}$ & 26,57 & 67,50 & 14,05 \\
\hline 5 & $\begin{array}{l}\text { Pangg } \\
\text { ung } \\
\text { Kidul }\end{array}$ & E1 & 8,39 & $\begin{array}{r}23,0 \\
7\end{array}$ & E3 & 24,31 & $\begin{array}{r}66,8 \\
4\end{array}$ & E2 & $\begin{array}{r}3,6 \\
7\end{array}$ & 10,08 & 36,37 & 7,57 \\
\hline 6 & $\begin{array}{l}\text { Pangg } \\
\text { ung } \\
\text { Lor }\end{array}$ & $\mathrm{F} 1$ & 97,81 & $\begin{array}{r}100 \\
00\end{array}$ & - & 0,00 & 0,00 & - & $\begin{array}{r}0,0 \\
0\end{array}$ & 0,00 & 97,81 & 20,36 \\
\hline 7 & $\begin{array}{l}\text { Plomb } \\
\text { okan }\end{array}$ & G1 & 17,34 & $\begin{array}{r}47,0 \\
6\end{array}$ & G2 & 19,51 & $\begin{array}{r}52,9 \\
4\end{array}$ & - & $\begin{array}{r}0,0 \\
0\end{array}$ & 0,00 & 36,85 & 7,67 \\
\hline 8 & $\begin{array}{l}\text { Purwo } \\
\text { sari }\end{array}$ & - & 0,00 & 0,00 & $\begin{array}{l}\mathrm{H} 1 \mathrm{H} 2 \mathrm{H} 3 \\
\mathrm{H} 4\end{array}$ & 33,22 & $\begin{array}{r}100 \\
00\end{array}$ & - & $\begin{array}{r}0,0 \\
0\end{array}$ & 0,00 & 33,22 & 6,91 \\
\hline 9 & $\begin{array}{l}\text { Tanjun } \\
\text { gmas }\end{array}$ & - & 0,00 & 0,00 & I2 I6 & 33,87 & $\begin{array}{r}46,0 \\
8 \\
\end{array}$ & I1 I3 I4 I5 & $\begin{array}{r}39, \\
63 \\
\end{array}$ & 53,92 & 73,50 & 15,30 \\
\hline & & 6 & 197,10 & $\begin{array}{r}41,0 \\
2 \\
\end{array}$ & 15 & 188,86 & $\begin{array}{r}39,3 \\
1 \\
\end{array}$ & 16 & 94,48 & $\begin{array}{r}9,6 \\
6 \\
\end{array}$ & 480,44 & 100,00 \\
\hline
\end{tabular}

Sumber: Hasil Analisis, 2020

1. Kecamatan Semarang Utara didominasi oleh permukiman dengan kualitas lingkungan baik, terdapat di 6 blok pada wilayah kelurahan Bulu Lor, Kuningan, Panggung Kidul, Panggung Lor dan Plombokan dengan persentase 41,02\% dari luas total permukiman (197,10 ha).

2. Permukiman dengan kualitas lingkungan sedang terdapat di 15 blok pada wilayah kelurahan Bandarharjo, Dadapsari, Kuningan, Panggung Kidul, Plombokan, Purwosari dan Tanjungmas dengan persentase 39,31\% dari luas total permukiman (188,86 ha).

3. Permukiman dengan kualitas lingkungan buruk terdapat di 16 blok pada wilayah kelurahan Bandarharjo, Bulu Lor, Kuningan, Panggung Kidul dan Tanjungmas dengan persentase $19,66 \%$ dari luas total permukiman (94,48 ha).

Gambar 5 menunjukkan persebaran tingkat kualitas lingkungan blok permukiman kawasan pesisir Kecamatan Semarang Utara. 


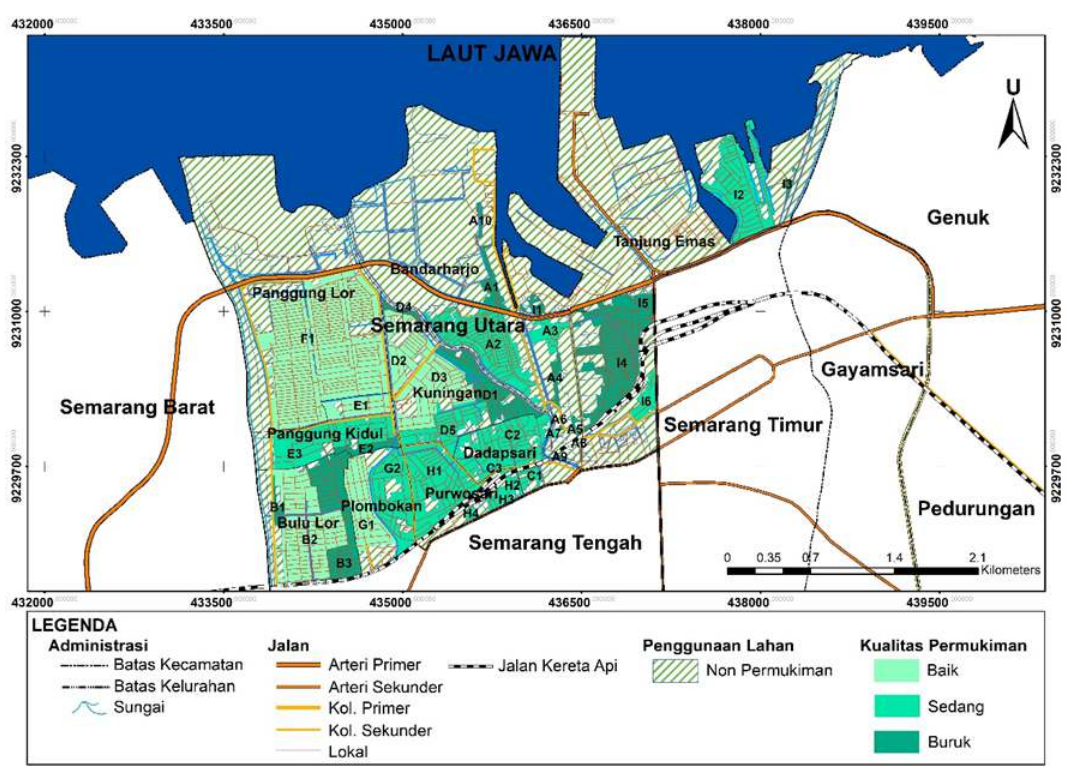

Sumber: Hasil Analisis, 2020

Gambar 5. Persebaran Kualitas Lingkungan Permukiman Kawasan Pesisir Kecamatan Semarang Utara

\subsection{Tipologi Permukiman Kawasan Pesisir Kecamatan Semarang Utara}

Tipologi permukiman kawasan pesisir Kecamatan Semarang Utara secara umum dapat dibedakan menjadi 2 (dua) kriteria yaitu permukiman kumuh dan permukiman tidak kumuh. Tabel 5 menunjukkan hasil Analisis Tipologi Permukiman Kawasan Pesisir Kecamatan Semarang Utara.

Tabel 5. Analisis Tipologi Permukiman Kawasan Pesisir Kecamatan Semarang Utara

\begin{tabular}{|c|c|c|c|c|c|c|c|c|c|}
\hline \multirow[b]{2}{*}{$\begin{array}{c}\text { Kelurah } \\
\text { an }\end{array}$} & \multirow[b]{2}{*}{ Blok } & \multirow[b]{2}{*}{$\begin{array}{l}\text { Kondisi } \\
\text { Permukim } \\
\text { an }\end{array}$} & \multirow{2}{*}{$\begin{array}{c}\text { Kualitas } \\
\text { Lingkun } \\
\text { gan } \\
\text { Permuki } \\
\text { man }\end{array}$} & \multicolumn{3}{|c|}{ Kondisi Sosial Ekonomi } & \multirow[b]{2}{*}{$\begin{array}{c}\text { Tipolog } \\
\text { i } \\
\text { Permu } \\
\text { kiman }\end{array}$} & \multirow[b]{2}{*}{$\begin{array}{l}\text { Luas } \\
\text { Blok } \\
\text { (ha) }\end{array}$} & \multirow{2}{*}{$\begin{array}{c}\text { Luas } \\
\text { Kelura } \\
\text { han } \\
\text { Total } \\
\text { (ha) }\end{array}$} \\
\hline & & & & $\begin{array}{c}\text { Kepada } \\
\text { tan } \\
\text { Pendud } \\
\text { uk } \\
\end{array}$ & $\begin{array}{c}\text { Pendidi } \\
\text { kan } \\
\text { Domina } \\
\text { n } \\
\end{array}$ & $\begin{array}{c}\text { Mata } \\
\text { Pencaharian } \\
\text { Dominan }\end{array}$ & & & \\
\hline \multirow{7}{*}{$\begin{array}{l}\text { Bandarh } \\
\text { arjo }\end{array}$} & A1 & $\begin{array}{l}\text { Kumuh } \\
\text { Sedang }\end{array}$ & Buruk & Rendah & SD & Buruh Industri & Tipe 8 & 4.70 & \multirow{7}{*}{246.49} \\
\hline & A2 & $\begin{array}{l}\text { Kumuh } \\
\text { Ringan }\end{array}$ & Sedang & Rendah & $\mathrm{SD}$ & Buruh Industri & Tipe 5 & 29.66 & \\
\hline & $\mathrm{A} 3$ & $\begin{array}{l}\text { Kumuh } \\
\text { Sedang }\end{array}$ & Sedang & Rendah & SD & Buruh Industri & Tipe 7 & 5.46 & \\
\hline & A4 & $\begin{array}{l}\text { Kumuh } \\
\text { Sedang }\end{array}$ & Buruk & Rendah & SD & Buruh Industri & Tipe 8 & 2.32 & \\
\hline & A5 & $\begin{array}{c}\text { Kumuh } \\
\text { Berat }\end{array}$ & Buruk & Rendah & SD & Buruh Industri & Tipe 10 & 0.54 & \\
\hline & A6 & $\begin{array}{c}\text { Kumuh } \\
\text { Berat }\end{array}$ & Buruk & Rendah & SD & Buruh Industri & Tipe 10 & 0.09 & \\
\hline & A7 & $\begin{array}{l}\text { Kumuh } \\
\text { Sedang }\end{array}$ & Sedang & Rendah & SD & Buruh Industri & Tipe 7 & 0.36 & \\
\hline
\end{tabular}


Jurnal Planologi Vol. 18 No. 1, April 2021

Available: http://jurnal.unissula.ac.id/index.php/psa

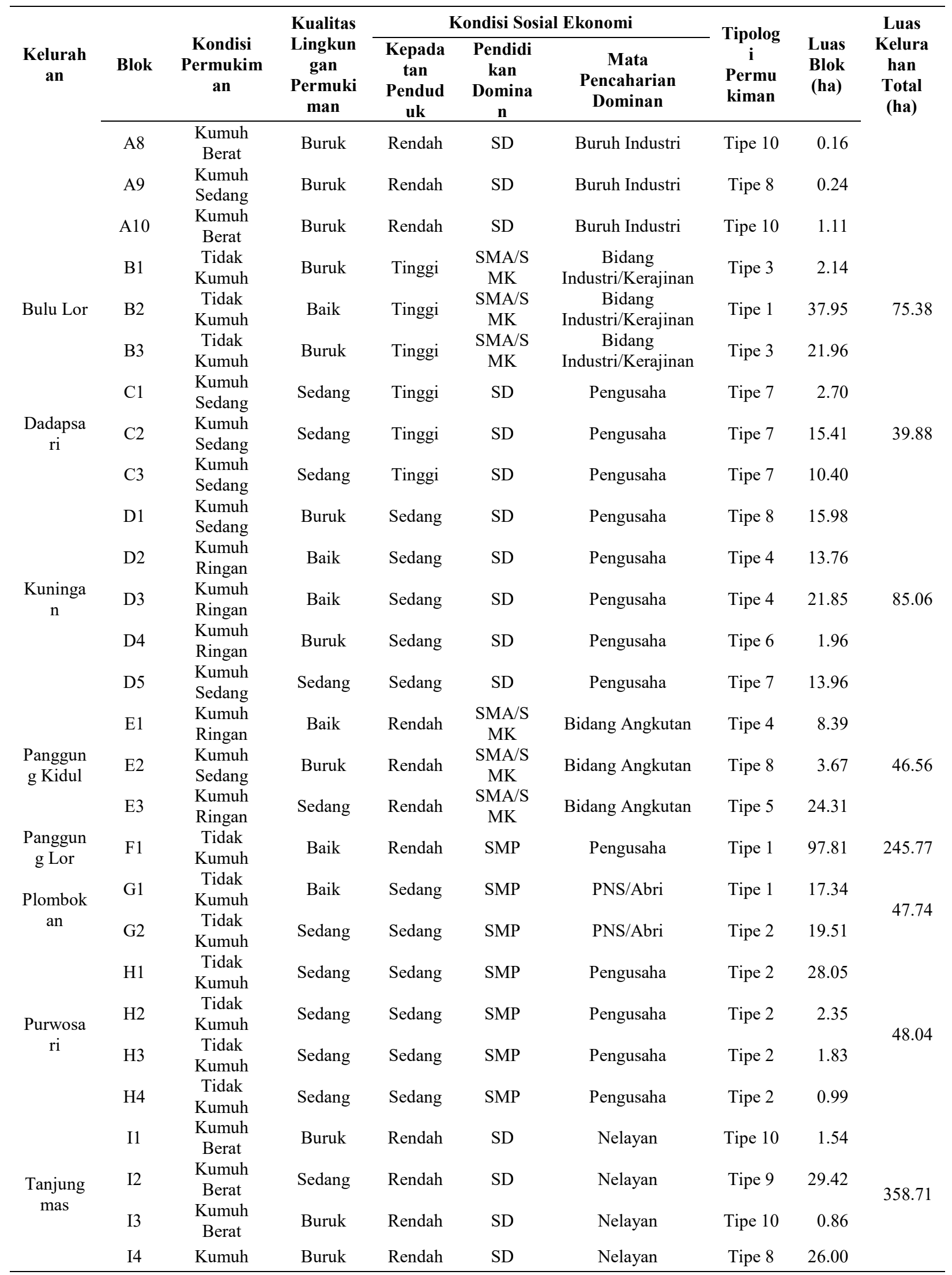

Rachmad Winarko Suhar Putra, Bitta Pigawati $\mathbf{5 6}$ Tipologi Permukiman Kawasan Pesisir Kecamatan Semarang Utara... 
Jurnal Planologi Vol. 18 No. 1, April 2021

\begin{tabular}{|c|c|c|c|c|c|c|c|c|c|}
\hline \multirow{5}{*}{$\begin{array}{c}\text { Kelurah } \\
\text { an }\end{array}$} & \multirow[b]{2}{*}{ Blok } & \multirow[b]{2}{*}{$\begin{array}{l}\text { Kondisi } \\
\text { Permukim } \\
\text { an }\end{array}$} & \multirow{2}{*}{$\begin{array}{c}\text { Kualitas } \\
\text { Lingkun } \\
\text { gan } \\
\text { Permuki } \\
\text { man }\end{array}$} & \multicolumn{3}{|c|}{ Kondisi Sosial Ekonomi } & \multirow[b]{2}{*}{$\begin{array}{c}\text { Tipolog } \\
\text { i } \\
\text { Permu } \\
\text { kiman }\end{array}$} & \multirow[b]{2}{*}{$\begin{array}{l}\text { Luas } \\
\text { Blok } \\
\text { (ha) }\end{array}$} & \multirow{5}{*}{$\begin{array}{c}\text { Luas } \\
\text { Kelura } \\
\text { han } \\
\text { Total } \\
\text { (ha) }\end{array}$} \\
\hline & & & & $\begin{array}{c}\text { Kepada } \\
\text { tan } \\
\text { Pendud } \\
\text { uk } \\
\end{array}$ & $\begin{array}{c}\text { Pendidi } \\
\text { kan } \\
\text { Domina } \\
\text { n }\end{array}$ & $\begin{array}{c}\text { Mata } \\
\text { Pencaharian } \\
\text { Dominan }\end{array}$ & & & \\
\hline & & Sedang & & & & & & & \\
\hline & I5 & $\begin{array}{l}\text { Kumuh } \\
\text { Sedang }\end{array}$ & Buruk & Rendah & $\mathrm{SD}$ & Nelayan & Tipe 8 & 11.23 & \\
\hline & I6 & $\begin{array}{l}\text { Kumuh } \\
\text { Sedang }\end{array}$ & Sedang & Rendah & $\mathrm{SD}$ & Nelayan & Tipe 7 & 4.45 & \\
\hline
\end{tabular}

Sumber: Hasil Analisis, 2020

Terdapat 10 (sepuluh) tipologi permukiman di kawasan pesisir kecamatan Semarang Utara yang dianalisis berdasarkan kualitas lingkungan permukiman, tingkat kekumuhan dan karakteristik sosial ekonomi penduduknya:

1. Tipologi Permukiman I Sebagian besar permukiman kawasan pesisir di kecamatan Semarang Utara masuk ke dalam tipologi permukiman I terdapat di Kelurahan Bulu Lor, Panggung Lor dan Plombokan dengan persentase 31,87\% dari luas total permukiman (153,10 ha). Karakteristiknya adalah sebagai berikut:

- Kondisi permukiman tidak kumuh;

- Kualitas lingkungan permukiman baik;

- Kepadatan penduduk rendah, sedang hingga tinggi;

- Tingkat pendidikan masyarakat paling banyak adalah SLTP dan SMA/SMK;

- Mata pencaharian masyarakat didominasi sebagai pengusaha, pns/abri serta di bidang industri/kerajinan.

2. Tipologi permukiman II. terdapat di Kelurahan Plombokan dan Purwosari dengan persentase $10,98 \%$ dari luas total permukiman (52,73 ha)Karakteristiknya adalah sebagai berikut:

- Kondisi permukiman tidak kumuh;

- Kualitas lingkungan permukiman sedang;

- Kepadatan penduduk sedang;

- Tingkat pendidikan masyarakat paling banyak adalah SLTP; dan

- Mata pencaharian masyarakat didominasi sebagai pengusaha dan PNS/ABRI.

3. Tipologi permukiman III terdapat di Kelurahan Bulu Lor dengan persentase 5,02\% dari luas total permukiman (24,10 ha). Karakteristiknya adalah sebagai berikut: 
- Kondisi permukiman tidak kumuh;

- Kualitas lingkungan permukiman buruk;

- Kepadatan penduduk tinggi;

- Tingkat pendidikan masyarakat paling banyak adalah SMA/SMK; dan

- Mata pencaharian masyarakat didominasi di bidang industri/kerajinan.

4. Tipologi permukiman IV terdapat di Kelurahan Kuningan dan Panggung Kidul dengan persentase $9,16 \%$ dari luas total permukiman ( 44,00 ha). Karakteristiknya adalah sebagai berikut:

- Kondisi permukiman kumuh ringan;

- Kualitas lingkungan permukiman baik;

- Kepadatan penduduk rendah hingga sedang;

- Tingkat pendidikan masyarakat paling banyak adalah SD dan SMA/SMK; dan

- Mata pencaharian masyarakat didominasi sebagai pengusaha dan di bidang angkutan.

5. Tipologi permukiman V terdapat di kelurahan Bandarharjo dan Panggung Kidul dengan persentase $11,23 \%$ dari luas total permukiman (53,97 ha). Karakteristiknya adalah sebagai berikut:

- Kondisi permukiman kumuh ringan;

- Kualitas lingkungan permukiman sedang;

- Kepadatan penduduk rendah;

- Tingkat pendidikan masyarakat paling banyak adalah SD dan SMA/SMK; dan

- Mata pencaharian masyarakat didominasi sebagai buruh industri dan di bidang angkutan.

6. Tipologi permukiman VI terdapat di kelurahan Kuningan dengan persentase $0,41 \%$ dari luas total permukiman (1,96 ha). Karakteristiknya adalah sebagai berikut:

- Kondisi permukiman kumuh ringan;

- Kualitas lingkungan permukiman buruk;

- Kepadatan penduduk sedang;

- Tingkat pendidikan masyarakat paling banyak adalah SD; dan

- Mata pencaharian masyarakat didominasi sebagai pengusaha. 
7. Tipologi permukiman VII terdapat di kelurahan Bandarharjo, Dadapsari, Kuningan dan Tanjungmas dengan persentase $10,98 \%$ dari luas total permukiman $(52,74$ ha). Karakteristiknya adalah sebagai berikut:

- Kondisi permukiman kumuh sedang;

- Kualitas lingkungan permukiman sedang;

- Kepadatan penduduk rendah, sedang hingga tinggi;

- Tingkat pendidikan masyarakat paling banyak adalah SD; dan

- Mata pencaharian masyarakat didominasi sebagai pengusaha, nelayan dan buruh industri.

8. Tipologi permukiman VIII terdapat di kelurahan Bandarharjo, Kuningan, Panggung Kidul dan Tanjungmas dengan persentase $13,35 \%$ dari luas total permukiman $(64,13$ ha). Karakteristiknya adalah sebagai berikut:

- Kondisi permukiman kumuh sedang;

- Kualitas lingkungan permukiman buruk;

- Kepadatan penduduk rendah hingga sedang;

- Tingkat pendidikan masyarakat paling banyak adalah SD dan SMA/SMK; dan

- Mata pencaharian masyarakat didominasi sebagai pengusaha, nelayan, buruh industri dan di bidang angkutan.

9. Tipologi permukiman IX terdapat di kelurahan Tanjungmas dengan persentase $6,12 \%$ dari luas total permukiman (29,42 ha). Karakteristiknya adalah sebagai berikut:

- Kondisi permukiman kumuh berat;

- Kualitas lingkungan permukiman sedang;

- Kepadatan penduduk rendah;

- Tingkat pendidikan masyarakat paling banyak adalah SD; dan

- Mata pencaharian masyarakat didominasi sebagai nelayan.

10. Tipologi permukiman $\mathrm{X}$ terdapat di kelurahan Bandarharjo dan Tanjungmas dengan persentase $0,89 \%$ dari luas total permukiman (4,30 ha). Karakteristiknya adalah sebagai berikut:

- Kondisi permukiman kumuh berat;

- Kualitas lingkungan permukiman buruk; 
Jurnal Planologi Vol. 18 No. 1, April 2021

- Kepadatan penduduk rendah;

- Tingkat pendidikan masyarakat paling banyak adalah SD; dan

- Mata pencaharian masyarakat didominasi sebagai nelayan dan buruh industri.

Gambar 6 menunjukkan persebaran tipologi permukiman kawasan pesisir Kecamatan Semarang Utara.

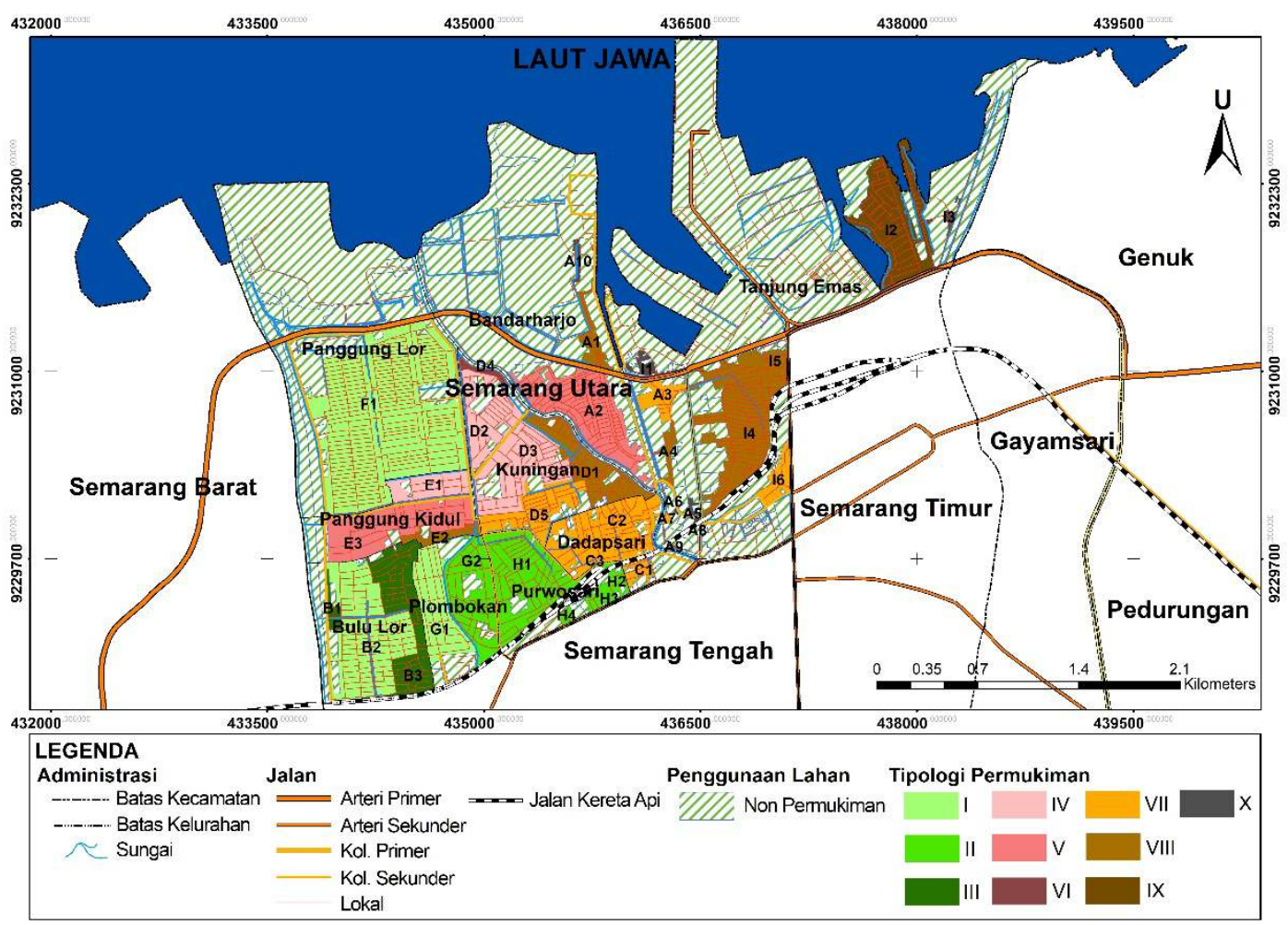

Sumber: Hasil Analisis, 2020

Gambar 6. Persebaran Tipologi Permukiman Kawasan Pesisir di Kecamatan Semarang Utara

\section{KESIMPULAN}

\subsection{Kesimpulan}

Beberapa kesimpulan yang dapat diperoleh berdasarkan hasil penelitian ini antara lain:

1. Penggunaan lahan permukiman di kecamatan Semarang Utara luasnya 480,44 Ha $(40,25 \%)$. Kelurahan Bandarharjo dan Tanjungmas yang lokasinya berbatasan langsung dengan Laut Jawa penggunaan lahan non permukimannya lebih besar dibanding luas permukiman, karena terdapat penggunaan lahan untuk komplek pelabuhan yang cukup luas, sedangkan penggunaan lahan non permukiman yang cukup luas di Kelurahan Panggung Lor 
disebabkan masih terdapatnya lahan kosong dalam komplek pelabuhan.

2. Terdapat 7 blok permukiman dengan tingkat kekumuhan berat di kawasan pesisir Kecamatan Semarang Utara yang berlokasi di Kelurahan Bandarharjo dan Kelurahan Tanjungmas. Kondisi ini dikarenakan jarak antar bangunan satu dengan bangunan lain yang relatif tidak ada jarak/menempel, letak permukiman berada di kawasan yang sangat strategis bagi kepentingan wilayah kota dan fungsi kawasan di sekitar permukiman sebagai pusat kegiatan bisnis kota, pemerintahan serta perkantoran.

3. Kecamatan Semarang Utara didominasi oleh permukiman dengan kualitas lingkungan baik, terdapat di 6 blok pada wilayah Kelurahan Bulu Lor, Kelurahan Kuningan, Kelurahan Panggung Kidul, Kelurahan Panggung Lor dan Kelurahan Plombokan dengan persentase $41,02 \%$ dari luas total permukiman yang terdapat di Kecamatan Semarang Utara

4. Tipologi permukiman kawasan pesisir Kecamatan Semarang Utara secara umum dapat dibedakan menjadi 2 (dua) kriteria yaitu permukiman kumuh dan permukiman tidak kumuh. Kawasan permukiman kumuh dicirikan dengan kondisi lingkungan yang buruk hingga sedang, sebagian besar penduduknya berpendidikan Sekolah Dasar (SD) yang bekerja sebagai buruh industri. Pada kawasan permukiman tidak kumuh menunjukkan kondisi lingungan yang baik, sebagian besar penduduknya mempunyai pendidikan SMA/SMK yang bekerja dalam bidang industri/kerajinan, namun pada kawasan lingkungan tidak kumuh ternyata masih ada kondisi lingkungan yang buruk. Kondisi ini terdapat pada blok permukiman B1 dan B3 di Kelurahan Bulu Lor. Hal ini dikarenakan kepadatan bangungan tinggi, (luas atap bangunan per blok permukiman $>78 \%$ ) dan tata letak bangunan buruk $(<22 \%$ ditata secara teratur per blok)

5. Secara rinci terdapat 10 (sepuluh) tipologi permukiman yang mempuyai karakter berbeda berdasarkan kualitas lingkungan permukiman, tingkat kekumuhan serta kondisi sosial ekonomi penduduknya. Tindak lanjut untuk perbaikan kawasan permukiman kumuh tergantung pada variable yang menunjukkan kondisi yang memerlukan perbaikan

\subsection{Saran}

Pada kawasan permukiman yang menunjukkan kondisi kumuh berat (Kelurahan Bandarharjo dan Kelurahan Tanjungmas) maupun yang mempunyai kualitas lingkungan buruk 
(Kelurahan Bulu Lor) dapat dilakukan dengan mengatur tata letak bangunan dan memperlebar jarak antar bangunan.

\section{DAFTAR PUSTAKA}

Ali, M. (2012). Kajian Dampak Perubahan Tutupan Lahan Terhadap Kejadian Banjir pada Lanskap DAS Ciliwung Hilir dengan Pendekatan Sistem Dinamik. Ipb. Institut Pertanian Bogor.

Anderson, J. R. (1976). A land use and land cover classification system for use with remote sensor data (Vol. 964). book, US Government Printing Office.

Arta, F. S., \& Pigawati, B. (2015). the Patterns and Characteristics of Peri-Urban Settlement in East Ungaran District, Semarang Regency. Geoplanning: Journal of Geomatics and Planning, 2(2), 103-115. https://doi.org/10.14710/geoplanning.2.2.103-115

Brueckner, J. K., \& Helsley, R. W. (2011). Sprawl and blight. Journal of Urban Economics, 69(2), 205-213. https://doi.org/10.1016/j.jue.2010.09.003

Direktorat Pengembangan Pemukiman Direktorat Jenderal Cipta Karya. (2006). Identifikasi Kawasan Pemukiman Kumuh Penyangga Kota Metropolitan. Direktorat Pengembangan Pemukiman Direktorat Jenderal Cipta Karya, 1-49.

Emmanuel, J. B. (2012). “ Housing Quality" To the Low Income Housing Producers in Ogbere , Ibadan , Nigeria, 35(December 2011), 483-494. https://doi.org/10.1016/j.sbspro.2012.02.114

Fichter, R. (1972). Freedom to build: Dweller control of the housing process. book, Macmillan.

Jaitman, L. (2013). Evaluation of Slum Upgrading Programs: A Literature Review. SSRN Electronic Journal, (November). https://doi.org/10.2139/ssrn.2305396

Jat, M. K., Choudhary, M., \& Saxena, A. (2017). Urban growth assessment and prediction using RS, GIS and SLEUTH model for a heterogeneous urban fringe. The Egyptian Journal of Remote Sensing and Space Science. https://doi.org/10.1016/j.ejrs.2017.02.002

Marfai, M. A., Cahyadi, A., \& Anggraini, D. F. (2013). Typology, dynamics, and potential 
disaster in the coastal area district Karst Gunungkidul. In Forum Geografi (Vol. 27, pp. 147-158). inproceedings.

Mintiea, T., \& Pigawati, B. (2018). Hubungan Karakteristik Permukiman Dengan Bentuk Adaptasi Masyarakat Terhadap Rob Di Pesisir Kota Semarang. Jurnal Pembangunan Wilayah \& Kota, 14(3), 199. https://doi.org/10.14710/pwk.v14i3.20259

Nafsi, N., Aspin, A., Santi, S., \& Belinda, S. (2019). KARAKTERISTIK PERMUKIMAN KUMUH (STUDI KASUS: KECAMATAN SEMARANG UTARA KOTA SEMARANG). Jurnal Malige Arsitektur (Media Arsitektur Lintas Generasi), 1(1).

Pemerintah Kota Semarang. (2011). RTRW Kota Semarang Tahun 2011-2031. Semarang. Retrieved from http://perpustakaan.bappenas.go.id/lontar/opac/themes/bappenas4/templateDet ail.jsp?id=142160\&lokasi=lokal

Pemerintah Republik Indonesia. Undang - Undang No 1 Tahun 2011 tentang Perumahan dan Kawasan Permukiman, Pub. L. No. 1 (2011). Indonesia.

Pigawati, B., \& Pradoto, W. (2014). Kebertahanan masyrakat pesisir Kota Semarang Terhadap banjir Rob. In Sustainable and resillient Cities and Regions (pp. 96-106).

Pigawati, B., Yuliastuti, N., \& Mardiansjah, F. H. (2017). Pembatasan Perkembangan Permukiman Kawasan Pinggiran Sebagai Upaya Pengendalian Perkembangan Kota Semarang. TATALOKA, 19(4), 306. https://doi.org/10.14710/tataloka.19.4.306-319

Pigawati, B., Yuliastuti, N., Mardiansjah, F. H., \& Suryani, M. A. (2019). Changes of Settlement Environmental Quality in Semarang City Center. IOP Conference Series: Earth and Environmental Science, 313(1), 12009. https://doi.org/10.1088/17551315/313/1/012009

Presiden Republik Indonesia. (2004). PP No 16 Tahun 2004 tentang Penatagunaan Tanah. Retrieved from http://www2.pom.go.id/public/hukum_perundangan/pdf/Pengamanan rokok bagi kesehatan.pdf

Ramadhan, R. A., \& Pigawati, B. (2014). Pemanfaatan Penginderaan Jauh Untuk Identifikasi Permukiman Kumuh Daerah Penyangga Perkotaan (Studi Kasus: Kecamatan Mranggen Kabupaten Demak). Geoplanning: Journal of Geomatics and 
Planning, 1(2), 102-113. https://doi.org/10.14710/geoplanning.1.2.102-113

Ratnaningtyas, H., \& Hadi, B. S. (2013). Pemanfaatan Citra Satelit Quickbird Untuk Evaluasi Pelaksanaan Rencana Detail Tata Ruang Kota Yogyakarta 1990-2010 (Kasus Bagian Wilayah Kota III). Geomedia: Majalah Ilmiah Dan Informasi Kegeografian, 11(1).

Walikota Semarang. (2014). SK Walikota Semarang Nomor 050/801/2014 tentang Penetapan Lokasi Lingkungan Perumahan dan permukiman Kumuh Kota Semarang. Semarang. 